\title{
Hospitalized cases of influenza A(H1N1)pdm09 in the French territories of the Americas, July 2009-March 2010
}

\author{
Marie Barrau, ${ }^{1}$ Sophie Larrieu, ${ }^{1}$ Sylvie Cassadou, ${ }^{1}$ Jean-Loup Chappert, ${ }^{1}$ \\ Philippe Dussart, ${ }^{2}$ Fatiha Najioullah, ${ }^{3}$ Séverine Matheus, ${ }^{2}$ Julien Renner, ${ }^{1}$ \\ Coralie Gasc, ${ }^{1}$ Philippe Quenel, ${ }^{1}$ and Martine Ledrans ${ }^{1}$
}

ABSTRACT Objective. To describe the methodology used for implementing a surveillance system specifically for influenza A(H1N1)pdm09 in the French West Indies and French Guiana during an outbreak of this new virus in 2009-2010, and to report its main results.

Methods. This was an observational descriptive study of confirmed and probable cases of influenza A(H1N1)pdm09 hospitalized for at least 24 hours in 23 July 2009-3 March 2010. Reverse transcription polymerase chain reaction was performed on nasopharyngeal swab samples according to the Centers for Disease Control and Prevention protocol. A probable case was defined as fever $\geq 38^{\circ} \mathrm{C}$ or aches or asthenia with respiratory symptoms (cough or dyspnea). All confirmed and probable hospitalized cases were reported, along with patient's age, sex, clinical condition at admission, place and length of hospitalization, antiviral treatment, underlying conditions, complications, and clinical evolution. A case was classified as severe if respiratory assistance or intensive care was required or if death resulted.

Results. A total of 331 confirmed and 16 probable cases were hospitalized, with a hospitalization rate ranging from 4.3 per 1000 clinical cases in Saint Martin to 10.3 in French Guiana. Of these, 36 were severe, and subsequently, 10 were fatal. The median length of stay was 4 days for non-severe cases and 9 days for severe $(\mathrm{P}<0.05)$. The mean patient age was 21 years, and severe cases were significantly older than non-severe (mean: 38 years versus 19 years, $\mathrm{P}<0.05)$. Underlying conditions associated with a higher risk of severity were 65 years of age or more $(R R=7.5,95 \% C I=4.2-13.3)$, diabetes $(R R=3.7,95 \% C I=1.5-9.4)$, cardiac insufficiency $(R R=8.4,95 \% C I=5.2-13.6)$, and morbid obesity $(R R=4.4,95 \% C I=1.8$ 10.4). Patients who received antiviral treatment within 2 days of symptom onset had shorter hospital stays (mean: 4 days versus 6.5 days, $\mathrm{P}<0.05$ ), and the illness tended to become less severe $(11.1 \%$ versus $19.0 \%, \mathrm{P}=0.13)$.

Conclusions. Active research of hospitalized cases enabled almost exhaustive surveillance. The pandemic's hospitalization rates and lethality were more moderate than expected. Some previously known underlying conditions of severity were confirmed during this outbreak. Furthermore, these results show the validity of early antiviral treatment.

Key words Influenza A virus, H1N1 subtype; epidemiological surveillance; sentinel surveillance; epidemiologic methods; virus diseases; French Guiana; Guadeloupe; Martinique; West Indies.

${ }^{1}$ Cellule de l'Institut de Veille Sanitaire en régions Antilles Guyane, Fort de France, Martinique. Send correspondence to Marie Barrau: marie_barrau@yahoo.fr
${ }^{2}$ Centre National de Référence des Arbovirus, Institut Pasteur de Guyane, Cayenne, French Guiana.
${ }^{3}$ Service de virologie-immunologie, Centre Hospitalier Universitaire, Fort de France, Martinique. 
On 25 April 2009, the World Health Organization (WHO) announced a "Public Health Emergency of International Concern" following the emergence of a new swine-origin influenza $\mathrm{A}(\mathrm{H} 1 \mathrm{~N} 1)$ pdm09 virus in Mexico and the United States of America (1). The virus was characterized by its geographically wide and rapid spread, and affected mainly healthy young adults (2). It had never been detected in humans prior to this outbreak. By 30 April 2010, a total of 217 countries had notified confirmed cases of pandemic influenza $\mathrm{A}(\mathrm{H} 1 \mathrm{~N} 1)$ pdm09 and the number of deaths was at least 17920 (3). To address the risk of a pandemic and to delay the spread of this new virus among the French territories of the Americas, the local epidemiology unit (Cellule Inter-Régionale d'Epidémiologie Antilles-Guyane, CIRE) of the Institut de Veille Sanitaire's (French Institute for Public Health Surveillance, InVS) implemented the same specific epidemiological surveillance system operating in France.

CIRE is composed of field epidemiologists practicing in French Guiana and the French West Indies (Guadeloupe, Martinique, Saint Barthélemy, and Saint Martin). These territories are quite similar to one another, the only main difference being the age of their populations: French Guiana's is younger, with $36.1 \%$ less than 15 years of age; while Guadeloupe's and Martinique's are somewhat older, with only $22.5 \%$ and $20.4 \%$ under 15 years, respectively (4). Table 1 shows the population base of each territory.

\section{Surveillance background}

Influenza $\mathrm{A}(\mathrm{H} 1 \mathrm{~N} 1) \mathrm{pdm} 09$ surveillance was performed in two phases. This study focused on the second phase. The first was a containment phase that ran from 29 April-22 July 2009; it involved epidemiologists detecting all imported cases.

TABLE 1. Population base and area of each French territory in the Region of the Americas, 2009

\begin{tabular}{lrr}
\hline & $\begin{array}{c}\text { Number of } \\
\text { inhabitants }\end{array}$ & Area $\left(\mathrm{km}^{2}\right)$ \\
\hline French Guiana & 226426 & 83846 \\
Guadeloupe & 408090 & 1628 \\
Martinique & 402499 & 1128 \\
Saint Barthélemy & 9057 & 21 \\
Saint Martin & 37461 & 54 \\
\hline
\end{tabular}

Initially, all individuals who fit the possible case definition (influenza-like symptoms and history of travel) were systematically hospitalized and isolated until biological diagnosis was determined. A nasopharyngeal swab was performed by clinicians to confirm diagnosis. From 22 June 2009 onwards, after the investigation of suspected cases was complete, every possible case was isolated in the patient's home and sampling was discontinued. Three confirmed cases were hospitalized in Martinique; two confirmed cases were detected in Guadeloupe and four in Saint Martin; and no confirmed cases were registered in Saint Barthélemy or French Guiana.

Following detection of a local viral transmission within the French territories, the second phase of surveillance was begun on 23 July 2009. Containment being considered no longer effective, it was decided that only measures to minimize the epidemic's impact would be taken. During this second phase, epidemiological surveillance was aimed at monitoring the epidemic's characteristics (number of cases, geographic distribution, and severity) and its impact. The dynamics of viral transmission were monitored by existing sentinel networks and cluster investigations. Nasal swabs were regularly performed for viral surveillance.

Because the influenza A(H1N1)pdm09 virus was emergent and its virulence was likely to evolve by mutating or reassorting with existing influenza viruses, health authorities feared high numbers of severe cases and deaths (5). The surveillance system was designed to detect any evolution of the virus' virulence and to characterize risk factors of disease severity.

The aim of this paper is to describe the methodology used for implementing the influenza $\mathrm{A}(\mathrm{H} 1 \mathrm{~N} 1)$ pdm09-specific surveillance system in the French West Indies and French Guiana during the 2009-2010 outbreak and to report its main results.

\section{MATERIALS AND METHODS}

This observational descriptive study of hospitalized cases of influenza A(H1N1)pdm09 ran from 23 July 2009-3 March 2010. Nasal swabs were performed within 48 hours of symptom onset on any patient presenting with fever $\geq 38^{\circ} \mathrm{C}$ or aches or asthenia with respiratory symptoms (cough or dyspnea). Samples were sent to the Centre National de Référence des Arbovirus at the Institut Pasteur de la Guyane, based in Cayenne, French Guiana, which is charged with virological surveillance of influenza viruses in the French territories of the Americas. Reverse transcription polymerase chain reaction (RT-PCR) for genome detection of influenza A(H1N1)pdm09 was performed on samples, according to the Centers for Disease Control and Prevention (CDC) protocol (6). As of 7 September 2009, the virologyimmunology laboratory at the Centre Hospitalier Universitaire in Fort-deFrance, Martinique, was able to perform genome detection of influenza A(H1N1)pdm09 for all samples taken in Martinique, using the CDC protocol (6).

A confirmed case was defined as one with a positive genome detection of influenza A(H1N1)pdm09. Because influenza $\mathrm{A}(\mathrm{H} 1 \mathrm{~N} 1)$ pdm09 was being widely detected and other Influenzavirus $A$ subtypes were not during the study period, a probable case was one that was either positive for Influenzavirus A, but did not have a positive subtype (H1N1)pdm09 detection, or one with influenza-like syndrome in a patient in whom a nasal swab could not be performed. All confirmed and probable cases of influenza A(H1N1)pdm09 hospitalized for at least 24 hours were included.

Clinicians were urged to perform nasal swabs on all hospitalized cases of influenza-like symptoms. Sentinel network practitioners performed nasal swabs on cases with influenza-like syndrome to estimate the number of persons having influenza $\mathrm{A}(\mathrm{H} 1 \mathrm{~N} 1) \mathrm{pdm} 09$ and to determinate which influenza viruses were circulating among the population. The hospitalization rate was calculated using the number of individuals hospitalized with probable or confirmed $\mathrm{A}(\mathrm{H} 1 \mathrm{~N} 1) \mathrm{pdm} 09$ and the population estimated to have this type of influenza.

A hospitalized case was considered to be severe if the patient needed ventilation, was in the Intensive Care Unit (ICU), or had died. Cases were reported in two complementary ways. First, physicians were asked to systematically report all hospitalized cases that fit the case definition by submitting a completed form to CIRE, whether or not a nasal swab had been performed. Data collected included demographics, date of swab, name of the ward that performed it, patient's health condition at 
admission, vaccines previously received, antiviral treatments administered, and clinical evolution. These were registered on the $\mathrm{VoozaFlu}^{\circledR}$ French National Database (EpiConcept, Paris, France).

Second, all laboratory-confirmed cases (hospitalized or not) were reported to CIRE by laboratories through a form that included patient identification, clinical symptoms, and dates of onset, sampling, and hospitalization, including hospital name and specific ward. This allowed detection of patients that were not declared by physicians.

Once biological diagnosis was established, CIRE contacted hospital wards with severe cases, on average, three times per week, to follow the patients' clinical evolution. For non-severe patients, the relevant hospital ward was called once per week. A post-discharge form was also collected in order to document disease evolution and potential complications. If a probable or confirmed case died, a group of experts was asked to determine whether the death was directly or indirectly attributable to the new virus, based on epidemiological, biological, and clinical arguments.

Comparison of characteristics according to outcomes was analyzed using chisquare test or Fisher's exact test according to theoretical distribution. Means comparisons were tested with Student's t-test. Analyses were performed with Stata ${ }^{\circledR}$ (StataCorp LP, College Station, Texas, United States).

\section{RESULTS}

From 23 July 2009-3 March 2010, there were 333 confirmed and 16 probable influenza A(H1N1)pdm09 cases that were hospitalized for more than 24 hours: 2 in Saint Barthélemy; 8 in Saint Martin; 76 in French Guiana, but 2 excluded due to missing data; 131 in Guadeloupe; and 132 in Martinique. Among the 16 probable cases, 14 were influenza A not subtyped and 2 were influenza-like illness. Among the 347 total cases, 36 (10.4\%) were classified as severe. Thirty-four of the severe cases were in the ICU where 8 resulted in death; another 2 fatalities occurred in other wards.

The hospitalization rates in Guadeloupe, Martinique, and Saint Martin were similar: 4.3, 6.1, and 5.2 per 1000 influenza $\mathrm{A}(\mathrm{H} 1 \mathrm{~N} 1) \mathrm{pdm} 09$ cases, respectively. In French Guiana, the rate was higher, reaching 10.3 per 1000 cases. In
Saint Barthélemy, the rate could not be calculated because there were too few swabs to estimate the number of affected subjects.

The distribution of severe cases and deaths among hospitalized cases by territory is shown in Table 2. The numbers were highest in Guadeloupe, with $17.6 \%$ of hospitalized cases classified as severe and $6.1 \%$ resulting in death. In Saint Barthélemy, the two hospitalized cases were severe. In Saint Martin, there were no severe cases. These two islands both registered 0 deaths.

\section{Demographics}

The female/male ratio was 1.4, similar in Saint-Martin, 1.0; Saint Barthélemy, 1.0; Martinique, 1.1; and Guadeloupe (1.3); but much higher in French Guiana, 2.9. The mean age of patients was 21 years, with a median of 17 and a range of 21 days -88 years. Figure 1 features the distribution of cases according to weeks of hospitalization among adults and children (less than 15 years of age). Most of the children $(79.2 \%)$ were hospitalized

TABLE 2. Distribution of severe cases and deaths among probable and confirmed A(H1N1)pdm09 hospitalized cases in the French West Indies and French Guiana, July 2009-March 2010

\begin{tabular}{|c|c|c|c|c|c|}
\hline \multirow[b]{2}{*}{ French territory in the Americas } & \multirow{2}{*}{$\begin{array}{c}\text { Number of } \\
\text { hospitalized cases }\end{array}$} & \multicolumn{2}{|c|}{ Severe cases } & \multicolumn{2}{|c|}{ Deaths } \\
\hline & & No. & $\%$ & No. & $\%$ \\
\hline Guadeloupe & 131 & 23 & 17.6 & 8 & 6.1 \\
\hline French Guiana & 74 & 7 & 9.5 & 1 & 1.4 \\
\hline Martinique & 132 & 4 & 3.0 & 1 & 0.8 \\
\hline Saint Barthélemy & 2 & 2 & 100.0 & 0 & 0.0 \\
\hline Saint Martin & 8 & 0 & 0.0 & 0 & 0.0 \\
\hline Total & 347 & 36 & 10.4 & 10 & 2.8 \\
\hline
\end{tabular}

FIGURE 1. Number of probable and confirmed A(H1N1)pdm09 hospitalizations among adults and children according to week of hospitalization in the French West Indies and French Guiana ( $n=346$ ), weeks 2009-31-2010-03

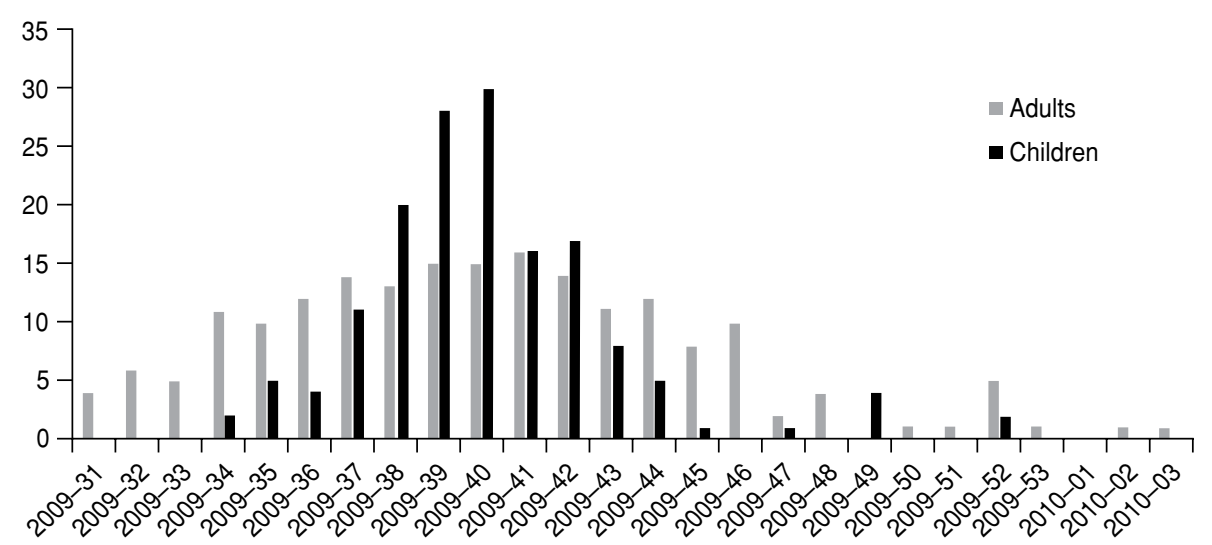


95\% Confidence Interval $[\mathrm{CI}]=4.2-3.3$ ); whereas this proportion was only $3.4 \%$ among children less than 10 years of age.

Pregnancy. Pregnancy was another risk group identified. Of 134 hospitalized women 15-45 years of age, 61 were pregnant $(45.5 \%)$. Of the 46 pregnant women for whom the week of pregnancy was known, $2(4.3 \%)$ were in the first trimester, $13(28.3 \%)$ in the second trimester, and $31(67.4 \%)$ in the third trimester. Pregnancy was negatively associated with severity $(\mathrm{RR}=0.3,95 \% \mathrm{CI}=0.1-0.9)$.

Underlying medical conditions. Information on underlying medical conditions was available for 241 cases $(69.5 \%)$ and is presented in Table 3. Most of these patients $(89.6 \%)$ had at least one known underlying medical condition. The most common were asthma (22.4\%) and sickle cell anemia (12.9\%). Only $2.5 \%$ of the patients had morbid obesity. All patients who died presented underlying conditions, except for a 13-month old infant with no known underlying condition. Three of the six patients hospitalized with morbid obesity developed severe disease and died. The following conditions were found to be associated with a higher risk of severity: diabetes $(\mathrm{RR}=3.7,95 \% \mathrm{CI}=1.5-9.4)$, cardiac insufficiency $(\mathrm{RR}=8.4,95 \% \mathrm{CI}=5.2-13.6$ ) and morbid obesity $(\mathrm{RR}=4.4,95 \% \mathrm{CI}=$ 1.8-10.4).

Timeliness of treatment. Table 4 describes the mean time interval for the following periods: time from onset of symptoms to hospital admission, length of hospital stay, time from onset of symptoms to treatment administration, and time from hospital admission to treatment administration. The average period from the onset of illness to hospital admission was 1.9 days (median: 1 day; range: 0-31). It tended to be longer for severe cases (mean: 2.5 days; range: 0-11) than for non-severe ones (mean: 1.8 days; range: $0-31$ ), but the difference was not significant. Patients were hospitalized for an average of 4.5 days (median: 3; range: 1-56) and mean length of stay was longer for severe cases (9.3 days) than for non-severe cases (4 days) $\left(P<10^{-4}\right)$.

Data on administration of an antiviral treatment-most often, oseltamivir therapy-was available for $252(81.0 \%)$ non-severe and $31(86.1 \%)$ severe cases, with $202(80.2 \%)$ and $29(93.5 \%)$, respectively, having received it.

Interval time between onset of symptoms and therapy administration following hospital-admission was known for 211 patients $(91.3 \%$ of those who received antiviral treatment); this was similar for both severe and non-severe cases (1.3 days). Therapy was administered within 2 days after onset of symptoms for $153(72.5 \%)$ of these. Fewer of the severe cases received antivirals within 2 days compared to the non-severe cases (60.7\% versus $74.3 \%, P=0.2$ ), but the mean delay of administration between severe and non-severe cases was similar (1 day). Patients who received therapy within 2 days after onset of symptoms had a shorter hospital stay than those who did not (mean: 4 versus 6.5 days, $P<0.006)$.

Complications. Complications were reported for 95 patients $(27.4 \%$ of hospitalized cases), and were more frequent among the severe cases $(80.6 \%)$ than the non-severe $(21.2 \%)$. A description of these complications is presented in Table 5. The most frequent complications observed were pneumonia $(29.5 \%)$, acute respiratory distress syndrome (26.3\%), and underlying disease decompensation (15.8\%). They were largely predominant among severe cases $(55.2 \%, 31.0 \%$, and $27.6 \%$, respectively); whereas non-severe cases were also likely to suffer from other complications.

\section{DISCUSSION}

The surveillance performed in the five French territories in the Americas allowed the authors to describe the characteristics of hospitalized patients during the whole epidemic, and to follow the occurrence of severe forms in real time.

\section{Hospitalization rate}

Exhaustivity is one of this study's main strengths, since all the patients hospitalized in the five French territories of the Americas during the influenza A(H1N1)pdm09 epidemic were included. Indeed, cases were reported through two complementary systems, so it can be assumed that very few biologicallyconfirmed cases were not identified. Therefore, the hospitalization rate could

TABLE 3. Underlying conditions of probable and confirmed hospitalized influenza A(H1N1)pdm09 patients according to severity in the French West Indies and French Guiana $(n=241)$, July 2009-March 2010

\begin{tabular}{|c|c|c|c|c|c|c|c|c|c|c|c|}
\hline \multirow[b]{3}{*}{ Underlying condition } & \multirow{2}{*}{\multicolumn{2}{|c|}{$\begin{array}{c}\text { All } \\
\text { patients } \\
(n=241)\end{array}$}} & \multirow{2}{*}{\multicolumn{2}{|c|}{$\begin{array}{c}\text { Non-severe } \\
\text { patients } \\
(n=211)\end{array}$}} & \multicolumn{4}{|c|}{ Severe patients $(n=30)$} & \multirow[b]{3}{*}{ Risk ratio ${ }^{a}$} & \multirow[b]{3}{*}{$95 \% \mathrm{Cl}$} & \multirow[b]{3}{*}{$P^{\mathrm{b}}$ - value } \\
\hline & & & & & \multicolumn{2}{|c|}{$\begin{array}{c}\text { All severe } \\
(n=30)\end{array}$} & \multicolumn{2}{|c|}{$\begin{array}{l}\text { Deaths } \\
(n=10)\end{array}$} & & & \\
\hline & No. & $\%$ & No. & $\%$ & No. & $\%$ & No. & $\%$ & & & \\
\hline None & 25 & 10.4 & 18 & 8.5 & 7 & 23.3 & 1 & 10.0 & & & \\
\hline Asthma & 54 & 22.4 & 48 & 22.7 & 6 & 20.0 & 1 & 10.0 & 0.9 & $0.4-2.0$ & 0.80 \\
\hline Chronic respiratory disease & 22 & 9.1 & 19 & 9.0 & 3 & 10.0 & 0 & 0.0 & 1.1 & $0.4-3.4$ & 0.80 \\
\hline Diabetes & 7 & 2.9 & 4 & 1.9 & 3 & 10.0 & 0 & 0.0 & 3.8 & $1.5-9.4$ & 0.01 \\
\hline Morbid obesity & 6 & 2.5 & 3 & 1.4 & 3 & 10.0 & 3 & 30.0 & 4.4 & $1.9-1.4$ & $<0.01$ \\
\hline Sickle cell anemia & 31 & 12.9 & 30 & 14.2 & 1 & 3.3 & 0 & 0.0 & 0.3 & $0.0-1.7$ & 0.11 \\
\hline Cardiac insufficiency & 7 & 2.9 & 1 & 0.5 & 6 & 20 & 2 & 20.0 & 8.3 & $5.3-13.0$ & $<0.01$ \\
\hline Cancer & 3 & 1.2 & 2 & 0.9 & 1 & 3.3 & 1 & 10.0 & 2.8 & $0.5-14.3$ & 0.30 \\
\hline Alcoholism with chronic hematopathy & 1 & 0.4 & 0 & 0.0 & 1 & 3.3 & 1 & 10.0 & 8.5 & $6.2-11.5$ & 0.10 \\
\hline Renal insufficiency & 6 & 2.5 & 6 & 2.8 & 0 & 0.0 & 0 & 0.0 & 0.0 & - & 0.40 \\
\hline Immune disorders & 4 & 1.7 & 4 & 1.9 & 0 & 0.0 & 0 & 0.0 & 0.0 & - & 0.40 \\
\hline
\end{tabular}

a Risk Ratio of severity.

b Chi-squared or Fisher's exact test used according to theoretical distribution. 
TABLE 4. Time intervals for non-severe and severe probable and confirmed $A(H 1 N 1) p d m 09$ cases in the French West Indies and French Guiana, July 2009-March 2010

\begin{tabular}{lcccr}
\hline \multicolumn{1}{c}{ Mean time interval (in days) } & $\begin{array}{c}\text { Non-severe } \\
\text { cases }\end{array}$ & $\begin{array}{c}\text { Severe } \\
\text { cases }\end{array}$ & $\begin{array}{c}\text { All } \\
\text { cases }\end{array}$ & $P$ value $^{\text {a }}$ \\
\hline $\begin{array}{l}\text { Onset of symptoms to hospital admission }(n=322) \\
\text { Length of hospital stay }(n=347)\end{array}$ & 1.8 & 2.5 & 1.9 & 0.12 \\
$\begin{array}{l}\text { Onset of symptoms to antiviral treatment } \\
\quad \text { administration }(n=211)\end{array}$ & 4.0 & 9.3 & 4.5 & $<0.01$ \\
$\begin{array}{l}\text { Hospital admission to antiviral treatment administration } \\
(n=209)\end{array}$ & 2.6 & 2.9 & 2.7 & 0.76 \\
\hline a Student's t-test un & 1.3 & 1.3 & 1.3 & 1.00 \\
\hline
\end{tabular}

a Student's t-test used.

TABLE 5. Complications among patients with severe or non-severe, probable or confirmed influenza A(H1N1)pdm09 in the French West Indies and French Guiana $(n=290)$, July 2009-March 2010

\begin{tabular}{|c|c|c|c|c|c|c|}
\hline \multirow[b]{2}{*}{ Complications } & \multicolumn{2}{|c|}{$\begin{array}{c}\text { Non-severe cases } \\
(n=66)\end{array}$} & \multicolumn{2}{|c|}{$\begin{array}{c}\text { Severe cases } \\
\quad(n=29)\end{array}$} & \multicolumn{2}{|c|}{$\begin{array}{c}\text { Total } \\
(n=95)\end{array}$} \\
\hline & No. & $\%$ & No. & $\%$ & No. & $\%$ \\
\hline Pneumonia & 12 & 18.2 & 16 & 55.2 & 28 & 29.5 \\
\hline Acute respiratory distress syndrome & 16 & 24.2 & 9 & 31.0 & 25 & 26.3 \\
\hline Underlying disease decompensation & 7 & 10.6 & 8 & 27.6 & 15 & 15.8 \\
\hline Neurologic viral infection & 6 & 9.1 & 1 & 3.4 & 7 & 7.4 \\
\hline Multivisceral failure & 3 & 4.5 & 1 & 3.4 & 4 & 4.2 \\
\hline Cardiac viral infection & 0 & 0.0 & 1 & 3.4 & 1 & 1.1 \\
\hline
\end{tabular}

be determined for each territory. In French Guiana, it was very close to the one observed in metropolitan France (about 1\%) (7). In the other territories, it was even lower $(0.4 \%-0.6 \%)$.

\section{Risk groups}

Age. Since the emergence of the new influenza $\mathrm{A}(\mathrm{H} 1 \mathrm{~N} 1)$ pdm09, the predominantly young age of the hospitalized patients has been one of the epidemic's defining traits. The pandemic risk assessment carried out by the European Centre for Disease Prevention and Control (ECDC) in December 2009 (8) confirmed this: nearly $80 \%$ of all cases were among those less than 30 years of age (9 813 cases of influenza A(H1N1)pdm09 in 28 European countries). This underrepresentation of older people may be partly attributed to immunity acquired during the 1918 influenza A(H1N1) pandemic (8). This was also observed by the present study: $34.0 \%$ of hospitalized patients were less than 10 years of age; $71.8 \%$, under 30 years; and only $2.6 \%$ were more than 65 years. This is consistent with previous studies showing that about $70 \%$ of patients hospitalized for influenza $\mathrm{A}(\mathrm{H} 1 \mathrm{~N} 1) \mathrm{pdm} 09$ are less than 30 years old (9-15), and fewer than 5\% are 65 years of age or more (16).

This contrasts strongly with seasonal influenza-a study in the United States showed that those 65 years of age or more account for nearly $50 \%$ of hospitalizations (17). On the other hand, although they represented a small proportion of hospitalized cases in the present study, elderly people were more likely to have a severe form of the disease $(66.7 \%$ of hospitalized cases among this population were severe), as previously shown by others $(8,15,18)$.

Pregnancy. Pregnant women are known to be at higher risk of seasonal and pandemic influenza-related illness and death (19) and were also identified as having a higher risk of ICU admission during the influenza A(H1N1)pdm09 epidemic in France (20). In the present study, the prevalence of pregnancy was higher than that of other studies $(10,11$, $18,21,22)$; however, there was one study that also notified an over-representation of pregnant women (23).

Underlying conditions. In metropolitan France, factors significantly associated with severe disease were increasing age and obesity (24). The case fatality rate also seems to be higher among the elderly: in Mexico, the mortality rate was higher among those 70 years of age or more (10\%) (25); in the present study, the highest fatality rate was also observed among the elderly (22.2\%). So, despite underrepresentation of older people among influenza A(H1N1)pdm09 cases, being elderly remained a risk factor for severe illness and mortality.

Asthma and chronic respiratory diseases were two of the main underlying medical conditions of the hospitalized patients-respectively, $22.4 \%$ and $9.1 \%$ of hospitalized cases-as described by several other studies $(10,12,15,18,26)$.

Morbid obesity was significantly associated with severity in this study. The potential role of obesity in influenza $\mathrm{A}(\mathrm{H} 1 \mathrm{~N} 1)$ pdm09-related severity was highlighted early by the CDC because it had not been identified previously as a risk factor for severe complications of seasonal influenza (27). A possible role through $\mathrm{T}$ cell memory response was recently raised; furthermore, extremely obese patients have a higher prevalence of co-morbid conditions, including chronic heart, lung, liver, and metabolic diseases that confer higher risk for influenza complications (28).

A non-negligible proportion of hospitalized cases had sickle cell disease $(12.9 \%)$, which is known to confer an increased susceptibility to infections (29), and seems to be a risk factor of influenza-related hospitalizations (30). This characteristic was not reported in other studies, probably because of a high prevalence of this disease in the French West Indies and a higher sensitization of the area clinicians.

Timeliness of treatment. In this study, patients who received antiviral treatment within 2 days had a shorter hospitalization, as previously shown (31) However, severity was not linked to an antiviral treatment administrated within 2 days of symptom onset, unlike the findings from three other studies (10, 22, 24). When necessary, clinicians administrated an antiviral treatment following national recommendations. Treatment had to be administrated within 48 hours of onset of symptoms, but that was not systematically respected because of the delay in hospitalization. Moreover, antiviral treatment was distributed only by hospitals until 10 December 2009, which may have delayed administration of treatment. However, in the present study, delaying antiviral administration and delaying hospitalization were not associated with complications.

Female/male ratio. When compared to results observed in Europe among pa- 
tients hospitalized during the $\mathrm{A}(\mathrm{H} 1 \mathrm{~N} 1)$ pandemic (8), one of the present study's distinctive results is the high female/ male ratio. The overrepresentation of pregnant women may partly explain this ratio. The highest proportion observed was in French Guiana where the birth rate (annual live-born births/total annual population) is also the highest (28.1 per 1000 in 2008); followed by Guadeloupe (prevalence of pregnant women; $19.1 \%$; and birth rate, $14.3 \%$ ); and Martinique, (prevalence of pregnant women, 9.1\%; birth rate, $13.4 \%$ ) (32).

\section{Study limitations}

The main limitation of this study was partly due to French recommendations. Some patients considered at-risk of severity were more likely to be hospitalized even though they did not present any symptom of severity: for instance, frequency of pregnancy among nonsevere cases appears to be higher than among the severe cases (restricted to women of reproductive age) and explains the negative association between pregnancy and severity. This could also be the case for underlying conditions that are well known by clinicians to be risk factors for severe influenza, e.g., asthma. On the contrary, conditions which are not well known by clinicians to be risk factors for severe influenza, such as morbid obesity, might not be adequately hospitalized, and thus, not be overrepresented in the group of nonsevere cases.

Another limit concerns the higher proportion of severe cases in Guadeloupe versus the other French territories. This difference is difficult to explain: the average period from onset of symptoms to hospital admission and length of hospital stay was not different from that of the other territories and does not suggest a lower quality of health care. It is possible that samples among severe cases were performed more systematically in Guadeloupe than in other territories. Despite the large communication campaigns and the recommendations to perform systematic nasal swabs for every suspect case of influenza, some infected patients may have been missed.

Finally, in the literature, ethnic origin was reported to be a risk group for severe disease $(11,12,22)$; however, French regulations do not allow this data to be collected for study.

\section{Conclusion and recommendations}

When all of the French territories in the Americas were hit by an influenza A(H1N1)pdm09 outbreak that led to hospital admissions, the wards were not overwhelmed, and severity and lethality appeared to be rather low.

In line with the other studies considered, this study emphasizes diabetes and morbid obesity-persistent public health concerns in the French territories-as being associated with a higher risk of severity of infectious diseases, such as influenza.

Furthermore, these results confirm the validity of early antiviral treatment by demonstrating that a short time from symptom onset to antiviral therapy treatment appears to shorten hospital stay.

Lastly, if ambulatory treatment could have been delivered during the period when intensity was highest, a significant number of hospitalizations might have been avoided.

Acknowledgements. The authors are grateful to all of the sentinel network practitioners, the clinicians, the Centre National de Référence des Arbovirus (Guyane, France), and the Service de virologie-immunologie of the Centre Hospitalier Universitaire (Martinique, France) for their participation in providing clinical data for this surveillance system. We also thank Vanessa Ardillon, Alain Blateau, Claude Flamand, and Jacques Rosine, epidemiologists at CIRE (Antilles Guyane), for their contribution to the surveillance system.

\section{REFERENCES}

1. World Health Organization. Swine influenza. Global alert and response, 25 April 2009. Available from: http://www.who.int/csr/ don/2009_04_25/en/index.html Accessed 9 May 2010.

2. World Health Organization. Influenza-like illness in the United States and Mexico. Global alert and response, 24 April 2009. Available from: http://www.who.int/csr/ don/2009_04_24/en/index.html Accessed 9 May 2010.

3. World Health Organization. Pandemic (H1N1) 2009-update 98. Global alert and response, 30 April 2009. Available from: http:// www.who.int/csr/don/2010_04_30a/en/ index.html Accessed 9 May 2010.

4. Institut national de la statistique et des études économiques. Résultats du recensement de la population, 2008. Available from: http:// www.recensement.insee.fr/home.action Accessed 19 January 2011.

5. Schnitzler SU, Schnitzler P. An update on swine-origin influenza virus A/H1N1: a review. Virus Genes. 2009;39(3):279-92.

6. World Health Organization. CDC protocol of real-time RTPCR for swine influenza A
(H1N1), revision 1. Available from: http:// www.who.int/csr/resources/publications/ swineflu/CDCRealtimeRTPCR_SwineH1As say-2009_20090430.pdf Accessed 30 April 2010.

7. Bonmarin I, Desenclos JC, Gastellu-Etchegorry M, Saura C, Lévy-Bruhl D. Grippe pandémique $\mathrm{A}(\mathrm{H} 1 \mathrm{N1}$ )2009: de l'estimé à l'observé. Available from: http://archives.invs.sante.fr/ beh/2010/24_25_26/beh_24_25_26_2010.pdf Accessed 11 April 2012.

8. European Centre for Disease Prevention and Control. 2009 influenza A(H1N1) pandemic: version 7, 17 December 2009. Available from: http:/ / ecdc.europa.eu/en/healthtopics / Documents/0908_Influenza_AH1N1_Risk Assessment.pdf Accessed 30 April 2010.

9. Tulloch F, Correa R, Guerrero G, Samaniego R, Garcia M, Pascale JM, et al. Profile of the first cases hospitalized due to influenza A (H1N1) in Panama City, Panama, MayJune 2009. J Infect Dev Ctries. 2009;3(11): 811-6.

10. Jain S, Kamimoto L, Bramley AM, Schmitz AM, Benoit SR, Louie J, et al. Hospitalized patients with $2009 \mathrm{H} 1 \mathrm{~N} 1$ influenza in the
United States, April-June 2009. N Engl J Med. 2009:361(20):1935-44.

11. Baker MG, Wilson N, Huang QS, Paine S, Lopez L, Bandaranayake D, et al. Pandemic influenza $\mathrm{A}(\mathrm{H} 1 \mathrm{~N} 1) \mathrm{v}$ in New Zealand: the experience from April to August 2009. Euro Surveill. 2009;14(34)

12. New South Wales public health network. Progression and impact of the first winter wave of the 2009 pandemic H1N1 influenza in New South Wales, Australia. Euro Surveill. 2009;14(42).

13. Cullen G, Martin J, O'Donnell J, Boland M, Canny M, Keane E, et al. Surveillance of the first 205 confirmed hospitalised cases of pandemic H1N1 influenza in Ireland, 28 April-3 October 2009. Euro Surveill. 2009;14(44).

14. Van 't Klooster TM, Wielders CC, Donker $\mathrm{T}$, Isken L, Meijer A, van den Wijngaard $\mathrm{CC}$, et al. Surveillance of hospitalisations for 2009 pandemic influenza $\mathrm{A}(\mathrm{H} 1 \mathrm{~N} 1)$ in the Netherlands, 5 June-31 December 2009. Euro Surveill. 2010;15(2).

15. Louie JK, Acosta M, Winter K, Jean C, Gavali $\mathrm{S}$, Schechter R, et al. Factors associated with death or hospitalization due to pandemic 
2009 influenza A(H1N1) infection in California. JAMA. 2009;302(17):1896-902.

16. World Health Organization. Human infection with pandemic A(H1N1) 2009 influenza virus: clinical observations in hospitalized patients, Americas, July 2009-update. Weekly Epidemiol Rec. 2009;30:305-8.

17. European Centre for Disease Prevention and Control. Surveillance and studies in a pandemic in Europe, June 2009. Available from: http://www.ecdc.europa.eu/en/publica tions/Publications/0906_TER_Surveillance and_Studies_in_a_Pandemic_in_Europe.pdf Accessed 9 May 2010.

18. Centers for Disease Control and Prevention. Hospitalized patients with novel influenza $\mathrm{A}(\mathrm{H} 1 \mathrm{N1})$ virus infection, California, AprilMay 2009. MMWR. 2009;58:536-41.

19. Rasmussen S, Jamieson D, J.S. Bresee J. Pandemic influenza and pregnant women. Emerg Infect Dis. 2008;14(1):95-100.

20. Hanslik T, Boelle PY, Flahault A. Preliminary estimation of risk factors for admission to intensive care units and for death in patients infected with A(H1N1)2009 influenza virus, France, 2009-2010. PLoS Curr Influenza. 2010;RRN1150.

21. Webb SA, Pettila V, Seppelt I, Bellomo R, Bailey M, Cooper DJ, et al. Critical care services and 2009 H1N1 influenza in Aus- tralia and New Zealand. N Engl J Med. 2009;361(20):1925-34.

22. Zarychanski R, Stuart TL, Kumar A, Doucette S, Elliott L, Kettner J, et al. Correlates of severe disease in patients with 2009 pandemic influenza (H1N1) virus infection. CMAJ. 2010;182(3):257-64.

23. Denholm JT, Gordon CL, Johnson PD, Hewagama SS, Stuart RL, Aboltins C, et al. Hospitalised adult patients with pandemic (H1N1) 2009 influenza in Melbourne, Australia. Med J Aust. 2010;192(2):84-6.

24. Fuhrman C, Bonmarin I, Paty AC, Duport N, Chiron E, Lucas E, et al. Severe hospitalised 2009 pandemic influenza A(H1N1) cases in France, 1 July-15 November 2009. Euro Surveill. 2010;15(2).

25. Echevarria-Zuno S, Mejia-Arangure JM, MarObeso AJ, Grajales-Muniz C, Robles-Perez E, Gonzalez-Leon $\mathrm{M}$, et al. Infection and death from influenza A H1N1 virus in Mexico: a retrospective analysis. Lancet. 2009;374(9707):2072-9.

26. Center for Disease Control and Prevention. Patients hospitalized with 2009 pandemic influenza A (H1N1)-New York City, May 2009. MMWR. 2010;58(51):1436-40.

27. Center for Disease Control and Prevention. Intensive-care patients with severe novel influenza A (H1N1) virus infection, Michigan, June 2009. MMWR. 2009;58(27):749-52.
28. Karlsson EA, Sheridan PA, Beck MA. Dietinduced obesity impairs the $T$ cell memory response to influenza virus infection. J Immunol. 2010;184(6):3127-33.

29. Booth C, Inusa B, Obaro SK. Infection in sickle cell disease: a review. Int J Infect Dis. 2010;14(1):e2-12.

30. Bundy DG, Strouse JJ, Casella JF, Miller MR. Burden of influenza-related hospitalizations among children with sickle cell disease. Pediatrics. 2010;125(2):234-43.

31. Verrall A, Norton K, Rooker S, Dee S, Olsen $\mathrm{L}$, Tan $\mathrm{CE}$, et al. Hospitalizations for pandemic (H1N1) 2009 among Maori and Pacific Islanders, New Zealand. Emerg Infect Dis. 2010;16(1):100-2.

32. Institut national de la statistique et des études économiques. Fécondité-espérance de vie-mor talité, 2008. Available from: http://www.in see.fr $/ \mathrm{fr} /$ themes $/$ theme.asp?theme $=2 \&$ sous theme $=2 \&$ nivgeo $=0 \&$ type $=2$ Accessed 6 May 2010 .

Manuscript received on 19 September 2011. Revised version accepted for publication on 18 April 2012.

RESUMEN Objetivo. Describir la metodología usada para implementar un sistema de vigilancia específico para la gripe A(H1N1)pdm09 en las Indias Occidentales Francesas y la Guayana Francesa durante un brote ocasionado por este virus nuevo ocurrido en 20092010 y presentar sus principales resultados.

Casos hospitalizados de gripe $A(\mathrm{H} 1 \mathrm{~N} 1)$ pdm09 en los territorios franceses de las Américas entre julio de 2009 y marzo de 2010

Métodos. Se llevó a cabo un estudio de observación descriptivo de los casos confirmados y probables de gripe por $\mathrm{A}(\mathrm{H} 1 \mathrm{~N} 1) \mathrm{pdm} 09$ hospitalizados durante al menos 24 horas entre el 23 de julio de 2009 y el 3 de marzo de 2010. De conformidad con el protocolo de los Centros para el Control y la Prevención de Enfermedades se realizó la prueba de reacción en cadena de la polimerasa con transcripción inversa en muestras de hisopados nasofaríngeos. Se definió como caso probable la presencia de fiebre $\geq 38^{\circ} \mathrm{C}$ o dolores o astenia junto con síntomas respiratorios (tos o disnea). Se comunicaron todos los casos hospitalizados confirmados y probables junto con la edad, el sexo, la situación clínica del paciente en el momento del ingreso, el lugar y la duración de la hospitalización, el tratamiento antivírico, las enfermedades subyacentes, las complicaciones y la evolución clínica. Se clasificaron como graves los casos que requirieron asistencia respiratoria o cuidados intensivos o provocaron la muerte.

Resultados. Fueron hospitalizados en total 331 casos confirmados y 16 probables, con una tasa de hospitalización que osciló entre 4,3 por cada 1000 casos clínicos en San Martín y 10,3 por cada 1000 en la Guayana Francesa. De ellos, 36 fueron graves y 10 llevaron posteriormente a la muerte del paciente. La mediana de la duración de las hospitalizaciones fue de 4 días para los casos no graves y de 9 días para los graves $(P<0,05)$. La edad media de los pacientes fue de 21 años, y los casos graves fueron significativamente de mayor edad que los no graves (media: 38 años frente a 19 años; $P<0,05)$. Las enfermedades subyacentes asociadas con un riesgo mayor de gravedad fueron edad de 65 años o más ( $R R=7,5$; IC de $95 \%=4,213,3)$, diabetes $(\mathrm{RR}=3,7$; IC de 95\% = 1,59,4), insuficiencia cardíaca $(\mathrm{RR}=8,4$; IC de $95 \%=5,213,6)$ y obesidad mórbida ( $R R=4,4$; IC de $95 \%=1,810,4)$. En los pacientes que recibieron tratamiento antivírico en el plazo de 2 días de la aparición de los síntomas las estancias hospitalarias fueron más breves (media: 4 días frente a 6,5 días; $P<0,05$ ) y la enfermedad tendió a presentar menor gravedad $(11,1 \%$ frente a $19,0 \% ; P=0,13)$.

Conclusiones. La investigación activa de los casos hospitalizados permitió una vigilancia casi exhaustiva. Las tasas de hospitalización y la letalidad de la pandemia fueron más moderadas que lo previsto. Durante este brote se confirmó la capacidad de algunas enfermedades subyacentes ya conocidas para aumentar la gravedad. Además, estos resultados demuestran la validez del tratamiento antivírico temprano.

Palabras clave Subtipo H1N1 del virus de la influenza A; vigilancia epidemiológica; vigilancia de guardia; métodos epidemiológicos; virosis; Guyana Francesa; Guadalupe; Martinica; Indias Occidentales. 